\title{
Non-alcoholic fatty pancreas disease - practices for clinicians
}

\author{
LARISA PINTE ${ }^{1}$, DANIEL VASILE BALABAN ${ }^{2,3}$, CRISTIAN BĂICUŞ $^{1,2}$, MARIANA JINGA $^{2,3}$ \\ 1“"Colentina" Clinical Hospital, Bucharest, Romania \\ ${ }^{2}$ "Carol Davila" University of Medicine and Pharmacy, Bucharest, Romania \\ 3“"Dr. Carol Davila" Central Military Emergency University Hospital, Bucharest, Romania
}

\begin{abstract}
Obesity is a growing health burden worldwide, increasing the risk for several diseases featuring the metabolic syndrome - type 2 diabetes mellitus, dyslipidemia, non-alcoholic fatty liver disease and cardiovascular diseases. With the increasing epidemic of obesity, a new pathologic condition has emerged as a component of the metabolic syndrome - that of non-alcoholic fatty pancreas disease (NAFPD). Similar to non-alcoholic fatty liver disease (NAFLD), NAFPD comprises a wide spectrum of disease - from deposition of fat in the pancreas - fatty pancreas, to pancreatic inflammation and possibly pancreatic fibrosis. In contrast with NAFLD, diagnostic evaluation of NAFPD is less standardized, consisting mostly in imaging methods. Also the natural evolution of NAFPD and its association with pancreatic cancer is much less studied. Not least, the clinical consequences of NAFPD remain largely presumptions and knowledge about its metabolic impact is limited. This review will cover epidemiology, pathogenesis, diagnostic evaluation tools and treatment options for NAFPD, with focus on practices for clinicians.
\end{abstract}

Key words: non-alcoholic fatty pancreas; metabolic syndrome; diabetes mellitus.

\section{INTRODUCTION}

The growing burden of obesity worldwide has led to a dramatic rise in patients suffering from metabolic syndrome. The excessive adipose tissue in obese individuals is endocrinologically active, leading to a proinflammatory state which generates several complications in target organs (liver, pancreas, heart and vessels) and even an increased risk for certain malignancies [1].

Similar to the liver, excessive lipid accumulation in the pancreas is known as steatosis. Fatty pancreas (FP), pancreatic steatosis or pancreatic lipomatosis are commonly reported in routine ultrasound examinations, but their significance is not clearly defined [1]. With the increasing epidemic of obesity, a new pathologic condition has emerged, that of pancreatic fat accumulation in the absence of alcohol use, but in association with features of the metabolic syndrome (MetS) - non-alcoholic fatty pancreas disease (NAFPD). As non-alcoholic fatty liver disease (NAFLD) is currently considered the hepatic manifestation of MetS, NAFPD could be thought of as the pancreatic equivalent of MetS.

Similar to non-alcoholic fatty liver disease (NAFLD), which has become a common cause of chronic liver disease, NAFPD comprises a wide spectrum of diseases - from deposition of fat in the pancreas (fatty pancreas, pancreatic steatosis), to pancreatic inflammation (non-alcoholic steatopancreatitis) and possible pancreatic fibrosis [2-3]. Despite the parallelism with NAFLD, which has been extensively investigated, our knowledge about NAFPD is still at the beginning, but interest in researching it is increasing. Currently, its clinical significance, outcome, relationship with chronic pancreatitis and pancreatic cancer are not well known yet [4]. Also, diagnosis is not standardized and treatment options are not evidence-based.

In the current review, we aimed to summarize and better delineate the features of NAFPD regarding nomenclature, clinical features, diagnosis and treatment.

\section{LITERATURE SEARCH}

For this purpose, we searched PubMed in December 2018 for all publications on NAFPD using several keywords that have been used to describe this condition - ("nonalcoholic fatty pancreas disease" OR "fatty pancreatic infiltration" OR "fatty pancreas") AND "metabolic syndrome". Articles were then grouped into case reports, original studies, editorials, reviews and meta-analysis. We selected 100 relevant articles on epidemiology, clinical features, diagnostic tools and treatment options and performed a narrative review (Table 1). 
Table 1

Literature search results

\begin{tabular}{|l|c|}
\hline \multicolumn{1}{|c|}{ Search term } & $\begin{array}{c}\text { Number of } \\
\text { articles }\end{array}$ \\
\hline "Nonalcoholic fatty pancreas disease" & 213 \\
\hline "Fatty pancreas" AND "metabolic syndrome" & 199 \\
\hline "Fatty pancreatic infiltration" & 263 \\
\hline
\end{tabular}

\section{EPIDEMIOLOGY}

First described in 1933 [5], NAFPD has not been extensively researched so far. Its epidemiology is not very well defined because of the differences in terminology and the absence of clear diagnostic criteria. Usually, FP is an incidental finding in abdominal imaging performed for other reasons and is not thought of in front of a patient with MetS to assess for pancreatic involvement.

There is limited data in the literature regarding the epidemiology of NAFPD. Studies in Asian populations have shown prevalence data ranging from 16 to $35 \%$ [6-8]. However, there is a clear strong association between NAFPD and NAFLD, which has been shown in several studies $-50-80 \%$ of NASH patients have FP on ultrasound examination, according to reported data [9-10], which makes NAFLD a risk category for NAFPD. Thus, considering the association of NAFLD with MetS, every patient with MetS should be evaluated for both NAFLD and NAFPD. Despite this close epidemiological relationship and similarities with liver pathology, there is also some data that differentiate between the two: (1) some imaging studies have found no association between NAFLD and NAFPD; (2) although there is significant pancreatic and liver fat loss in bariatric surgery-treated patients, liver fat loss seems to be higher [13] and, not in the least, (3) pancreatic fat correlated with NAFLD activity score, but after adjusting for BMI the relationship was not seen anymore [14, 11-16].

With respect to demographic characteristics, male gender, hispanics, older age and higher BMI have been reported to be associated with a higher prevalence of NAFPD [4, 7, 17-21]. Also, it is believed that maternal obesity can induce NAFPD in the offspring $[4,20]$.

There is also a lack of solid epidemiological data regarding the relationship of NAFPD with pancreatic diseases [1]. NAFPD has been reported to exacerbate the severity of acute pancreatitis (AP) and to increase complications after pancreatic surgery [22]; its role as a risk factor for chronic pancreatitis and pancreatic cancer is not clearly defined yet.
With regard to the relationship between NAFPD and acute pancreatitis (AP), studies have shown there is a direct toxic effect of fat on pancreatic acinar cells and islets, with fat infiltrates adjacent to acinar cells generating severe parenchymal damage in AP [23-24]. Although Sepe et al. found no association between FP and amylase/lipase serum levels [25], pancreatic steatosis has been reported to worsen the inflammation in AP. Studies have shown that the most severe damage is seen in necrosed adipocytes, with surrounding parenchymal necrosis, proving the direct connection between the severity of necrosis and location of fat in the proximity of acinar cells $[23,26]$. Thus, patients previously diagnosed with NAFPD who develop AP should be managed as potentially severe AP.

Concerning pancreatic surgery, one of the most common and potentially severe complications is pancreatic fistula (PF). Several studies have addressed the risk factors for PF formation in order to get insight into possible preventive measures, and FP has been identified as one of them. Rosso et al. have reported that fat infiltration of the pancreas $>10 \%$ represents a significant risk factor for $\mathrm{PF}$ [27] and thus patients considered for pancreatic surgery should undergo preoperative assessment for $\mathrm{FP}$ in order to stratify their risk for $\mathrm{PF}$ formation.

Not in the least, while evidence is building up for MetS as a risk factor for several types of cancer, concerns have been raised about the possible association of NAFPD with pancreatic neoplasia. Data on this association is however limited, Tomita et al. showing that fatty changes associated with inflammation in the pancreas constitute a predisposing factor for pancreatic carcinoma [28].

\section{PATHOLOGY}

From a pathological point of view, there should be a clear distinction between two phenomena which generate pancreatic steatosis - on the one hand there is fat accumulation associated with MetS, namely fatty infiltration which defines NAFPD, and, on the other hand, there is fatty replacement characterized by death of acinar cells, which get replaced by adipose tissue.

"Fatty replacement" occurs as a consequence of pancreatic cell apoptosis, caused by numerous factors, leading to adipocyte replacement. The leading factors for pancreatic parenchymal necrosis consist in: congenital diseases such as Cystic fibrosis, Shwachman-Bodian-Diamond syndrome, Johanson- 
Blizzard syndrome, heterozygous carboxyl-esterlipase mutations, alcohol abuse, viral infections (reovirus), iron overload (represented mainly by hemochromatosis, when the surplus iron is stored in the liver, heart, pancreas, and other organs), medications (corticosteroids, gemcitabine, rosiglitazone) or duct obstruction (obstructive chronic pancreatitis).

On the other hand, obesity is considered to be the main factor involving "fatty infiltration", leading to adipocyte infiltration in the pancreas, resulting in non-alcoholic fatty pancreas disease (NAFPD) [2, 25].

As such, when assessing for NAFPD, one should exclude conditions associated with fatty replacement - congenital diseases, steatogenic medications, viral infections, iron overload and obstructive pancreatitis [29] (Table 2).

Table 2

Mechanisms of fat deposition in the pancreas and related diseases

\begin{tabular}{|c|l|}
\hline \multicolumn{1}{|c|}{ Fatty infiltration } & \multicolumn{1}{|c|}{ Fatty replacement } \\
\hline NAFPD $=$ FP + MetS features & Congenital diseases \\
& Viral infections \\
& Iron overload \\
Drug-induced \\
Obstructive pancreatitis
\end{tabular}

Adipose tissue acts as an endocrine organ, sending signals to the brain, liver, skeletal muscle and pancreas. In conditions of weight gain, when adipose tissue expansion limit is exceeded, excess lipid is deposited in visceral and peripheral nonadipose tissue organs [30] such as the muscle, the liver and more recently the pancreas, causing visceral fat. At the same time, adipose tissue secretes less of the liporegulatory adipokine (TNF- $\alpha$, IL-6 and adiponectin), and more of the proinflammatory cytokines [31-32].

Compared to adipocytes, non-adipose cells have a limited capacity for free fatty acid storage [33]. When the storage capacity is exceeded, nonadipose cells become hypertrophic and undergo necrosis recruiting macrophages. Recruited macrophages infiltrate the hypertrophic adipose tissue and acquire the proinflammatory M1 phenotype causing a low grade inflammatory state [34].

Fatty infiltration of the pancreas is observed as ectopic adipocytes infiltrating the pancreatic tissue, causing initially pancreatic hypertrophy and hyperplasia [1] resulting in insulin resistance and dysfunction of pancreatic $\beta$-cells, with the risk of type 2 diabetes mellitus (T2DM) [21].

Unlike hepatic steatosis, where fat accumulates in hepatocytes, in "fatty infiltration" of the pancreas, triglycerides accumulate in adipocytes in the pancreatic tissue [35].
Histologically, two types of pancreatic adipocyte infiltration have been described: intralobular fat (accumulating with a scattered pattern) [4] and interlobular fat (with fat in the area between pancreatic lobules, mostly perivascular), the last type being specific for fatty infiltration in humans [36-37].

Microscopic analysis showed that in massive pancreatic steatosis, only pancreatic islet cells are resistant to fatty infiltration [38] raising the theory that exocrine pancreatic insufficiency might be the first manifestation of NAFPD. But the $\beta$-cell is also vulnerable to the lipotoxic effects of excess lipid flux to pancreatic islets, as well as to the damaging effects of the proinflammatory cytokines deriving from visceral obesity [2, 39-40].

It seems that ectopic fat deposition in nonadipose tissues and systemic low-grade inflammation activates the insulin resistance mechanism in insulin target tissues [21], which result in the metabolic syndrome phenotype [41-43]. FP is considered by some authors the first site of ectopic lipid deposition and as such, an early marker of insulin resistance [43].

\section{DIAGNOSING NAFPD}

With respect to diagnosis, it is important to note that not every fatty pancreas detected on ultrasound means NAFPD. According to its definition as obesity-associated accumulation of pancreatic fat, NAFPD diagnosis requires evidence of fatty infiltration of the pancreas and the associated MetS features, according to NCEP ATP III or IDF criteria (Table 3), in the absence of conditions associated with fatty replacement [44].

In contrast with NAFLD, there is currently no reliable biomarker to detect NAFPD and the diagnosis is mainly based on imaging methods [1]. Imaging tests aim at detecting and quantifying pancreatic fat, but this is not always easy to achieve noninvasively. Evaluation of pancreatic fat is even more challenging if we consider that the pancreatic parenchyma has variable shapes and sizes, margins are not always well demarcated and fatty distribution can be heterogenous [45] and not least, normal fatty degeneration occurs with increasing age [46-47]. Also, when using any imaging modality to evaluate pancreatic fat, we should acknowledge that there is a normal fatty infiltration of the pancreas, of up to $6.2 \%$ according to Singh et al., and only excessive fat accumulation over this cut-off should be considered FP.

Currently, there is no consensus regarding the first line imaging method to diagnose FP as the 
diagnostic accuracy is widely variable, but availability, costs and drawbacks also should be taken into account. Comparative head-to-head trials with different imaging methods have not been carried out so far, nor cut-off values validated for each imaging tool [29].

Table 3

Metabolic syndrome definition according to NCEP ATP III and IDF criteria

\begin{tabular}{|c|c|}
\hline International Diabetes Federation & $\begin{array}{c}\text { National Cholesterol Education } \\
\text { Program Adult Treatment Panel III }\end{array}$ \\
\hline \multicolumn{2}{|l|}{ 1. Central obesity (defined as waist circumference) } \\
\hline ethnicity specific values & $\begin{array}{l}\text { Males }>102 \mathrm{~cm}(>40 \text { in }) \\
\text { Females }>88 \mathrm{~cm}(>35 \text { in })\end{array}$ \\
\hline \multicolumn{2}{|c|}{ 2. Triglycerides $\geq 150 \mathrm{mg} / \mathrm{dL}(1.7 \mathrm{mmol} / \mathrm{L})$ or specific treatment for this lipid abnormality } \\
\hline \multicolumn{2}{|c|}{$\begin{array}{l}\text { 3. Reduced HDL cholesterol } \\
\quad<40 \mathrm{mg} / \mathrm{dL}(1.03 \mathrm{mmol} / \mathrm{L}) \text { in males } \\
\quad<50 \mathrm{mg} / \mathrm{dL}(1.29 \mathrm{mmol} / \mathrm{L}) \text { in females }\end{array}$} \\
\hline \multicolumn{2}{|c|}{ 4. Systolic blood pressure $\geq 130$ or diastolic blood pressure $\geq 85 \mathrm{~mm} \mathrm{Hg}$} \\
\hline \multicolumn{2}{|c|}{ 5. Fasting plasma glucose $\geq 100 \mathrm{mg} / \mathrm{dL}(5.6 \mathrm{mmol} / \mathrm{L})$ or previously diagnosed type 2 diabetes } \\
\hline \multicolumn{2}{|l|}{ Metabolic syndrome definition } \\
\hline $\begin{array}{l}\text { Central obesity } \\
\text { plus } \\
\text { any } 2 \text { of the remaining factors }\end{array}$ & Any 3 criteria \\
\hline
\end{tabular}

\section{Transabdominal ultrasound}

Transabdominal ultrasound (US), the most widely available, non-invasive tool for abdominal imaging, is frequently limited by the suboptimal visualization of the pancreas due to its deep retroperitoneal location, with interposition of the stomach or bowel content anteriorly. Some have reported lack of pancreas visualization in 1 out of 7 cases, particularly in obese individuals [7] - meaning the exact population in which we're looking for NAFPD. Pancreatic steatosis has been defined as an increased echogenicity of the pancreatic parenchyma compared to the liver or kidney (to the latter indirectly, first comparing hepatic and renal echogenicity, then comparing liver and pancreas echo contrast, as the pancreas and the kidney cannot be visualized in the same acoustic window) [43]. Severe pancreatic steatosis has also been defined when the parenchymal brightness is similar to that of the retroperitoneal fat [2]. Another confounder in US evaluation of the pancreas is that fibrosis also appears as hyperechoic, which can be misleading. Not least, the major limit of US is the fact that its operator dependent - in the study by Wang CY et al. reported mean interobserver percentage of agreement for ultrasound diagnosis of fatty pancreas was only $72 \%(\kappa=0.63)[19]$. Some authors have tried using some quantitative methods to assess pancreatic echogenicity - such as pancreato-perihepatic fat index, which has proved a strong association with MetS [48].

\section{Endoscopic ultrasound}

Compared to conventional US, endoscopic ultrasound (EUS) brings a higher frequency probe in close proximity of the pancreas, which translates into higher resolution and better visualization of the pancreas. Thus, EUS provides quality images for assessing the echotexture of the pancreas, but its major drawback is that it is invasive and carries associated procedural risks [49]. Several studies have researched factors associated with hyperechoic pancreas on EUS and have shown strong association with fatty liver, $\mathrm{BMI} \geq 30$, male gender, age over 60 years and hypertension $[10,25,50]$. As for transabdominal US, EUS is also operator-dependent and there is always the confounder that pancreatic hyperechogenicity does not always represent fatty infiltration and a differential with pancreatic fibrosis should be made [51].

Add-on EUS modules such as real-time elastography (RTE) have provided semiquantitative or quantitative information in several pancreatic diseases [52] and expectations were made for pancreatic steatosis too. However, RTE during EUS as a measure of pancreatic elasticity has proven to be correlated with pancreatic fibrosis, but not with fatty infiltration staged by histology [53-54].

\section{Computed tomography}

Computed-tomography (CT) is a good tool for assessing the pancreatic parenchyma. A noncontrast study is sufficient to evaluate for fatty infiltration of the pancreas, which will appear hypodense compared to the liver or spleen. Quantification of pancreatic steatosis is feasible by measuring the density (HU) in a selected region of interest (ROI). Its use for assessing FP is however limited by the radiation exposure, except for preoperative assessment in patients proposed for surgery, in whom the degree of pancreatic fat predicts clinical outcomes [55-57]. 
CT can provide quantitative assessment of pancreatic fat, with good correlation with histology such quantitative tools validated in studies are fat/ parenchymal ratio, difference between pancreatic and splenic attenuation and the pancreas-to-spleen attenuation ratio [58-59].

\section{Magnetic resonance imaging (MRI)}

Being a non-irradiating, non-invasive and safe method and having better accuracy for detecting lipomatosis, MRI is the preferred tool for evaluation of FP. There are several protocols to measure pancreatic fat using MRI, with MR spectroscopy being considered equivalent to histology [29]. Other studies have also shown comparable diagnostic accuracy of MRI with histology, which makes it the imaging method of choice for diagnosing pancreatic lipomatosis [29, 60-62].

\section{Histological assessment}

Histology remains the gold standard for assessing pancreatic fat content, but routine biopsy sampling to evaluate for FP is not feasible, even with minimally invasive techniques such as EUSguided fine needle aspiration (EUS-FNA).

Unlike NAFLD, when triglycerides accumulate mainly intracellular, in NAFPD there is an increased number of adipocytes, although intracellular fat accumulation in acinar and isle cells can also be found [29]. It is not well known if there is a different significance for intracellular or extracellular fat accumulation, but both mechanisms can induce pancreatic dysfunction - adipocytes by influencing acinar/islet cells by paracrine effect, while intracellular fat by inducing direct injury to these cells, as previously discussed [29].

Currently there is a histologic scoring system called pancreatic lipomatosis score (PLS), developed by van Geenen et al. [2, 14], which modifies the classification of Olsen [63].

\section{CLINICAL SIGNIFICANCE}

\section{Metabolic risk}

By definition, NAFPD includes features of MetS, which translates into strong association with type 2 DM, NAFLD and cardiovascular risk.

Although studies results, showing higher pancreatic fat deposits in patients with impaired glucose metabolism [20, 64], suggested that NAFPD might be a risk factor in developing type $2 \mathrm{DM}$, independent association of NAFPD and future type 2 DM evolution remain still under discussion $[4,21,65]$.
Regarding "fatty pancreas" and "fatty liver", recent studies showed that there is a significant association between these two entities. Patients with NAFLD also often suffer from NAFPD, while the presence of NAFLD in NAFPD patients is debated [7,20].

Also, Kim et al. showed that fatty pancreatic infiltration is associated with a higher risk of carotid atherosclerosis in non-obese patients with type 2 DM [66].

\section{Acute and chronic pancreatitis}

There is indirect evidence with respect to the relationship between NAFPD and AP, considering that obesity and MetS features are known risk factors for AP. Moreover, some studies have shown that fatty infiltration of the pancreas promotes more severe inflammation in AP [2, 23, 26].

With regard to its relationship with chronic pancreatitis (ChP), there is currently no evidence that NAFPD could cause ChP. In fact, studies have shown no correlation or even inverse correlation of FP with pancreatic fibrosis [67]. Recurrent acute pancreatitis in dysmetabolic patients can lead to morphologic changes of $\mathrm{ChP}$, but this by reduction in parenchyma and substitution with adipocytes and fibrosis, and not by fatty infiltration which defines NAFPD.

There has also been a debate in the literature about pancreatic hyperenzymemia and FP. Some authors have theorized that pancreatic hyperenzymemia in apparently healthy individuals could be due to FP and dyslipidemia, while others have shown that there is no connection to FP $[19,25$, 68-69].

\section{Exocrine pancreatic insufficiency (EPI)}

Given the toxic effect of fat on acinar cells, EPI could occur in the evolution of NAFPD, at least theoretically. However, there is currently no study looking at EPI in patients with pancreatic steatosis; only case reports of patients with severe fatty replacement who developed EPI were found in the literature search [70-73]. On the other hand, there are several studies reporting on EPI in type 2 DM patients; about one fifth of diabetics have exocrine insufficiency as measured by fecal elastase-1 (FE-1) [74-76], but FE-1 values do not seem to correlate with pancreatic steatosis [77].

\section{Pancreatic fistula}

Considering its close association with MetS, NAFPD seems to be a pathology for internal/ general medicine, but there is something in it for surgeons too. One of the most fearful complications of 
duodenopancreatectomy is formation of PF. Over the years, several modifiable and non-modifiable risk factors for PF development have been studied and addressed by technique improvement, drug interventions or post-operative management. Of these, fatty infiltration of the pancreas has been proven to be a significant risk factor for PF formation and preoperative evaluation for pancreatic steatosis is now considered a rational step for risk stratification of patients [27, 29].

\section{Pancreatic cancer (PC)}

While evidence is building up that metabolic disturbances are associated with an increased risk for certain types of cancer [78-79], a question has emerged about the risk of PC in NAFPD. Obesity is a well-known risk factor for PC [80] and there are some preliminary data to support an association between FP and pancreatic cancer too. The proposed mechanism of carcinogenesis in NAFPD is by means of adipocyte-mediated chronic inflammation, similar to what occurs in NAFLD [2, 29].

Besides the increased risk for PC, NAFPD also seems to contribute to worse outcomes of PC by altering the tumor microenvironment, compared to patients with lean pancreas $[55,81]$ who develop cancer.

Taking into account the increasing trend in mortality for PC [82], further research on the association between NAFPD and cancer is warranted.

\section{TREATMENT}

Being recently recognized as a new entity of the metabolic syndrome, research regarding NAFPD treatment is limited. In fact, until now no standard treatment has been proposed for NAFPD patients.

\section{General}

Having in mind that obesity represents the main cause for pancreatic fatty infiltration, according to several studies, weight loss with or without bariatric endoscopy/surgery [83-86] might represent the easiest way to reduce pancreatic fat content. Interestingly, despite the association between NAFLD and NAFPD, when patients undergo bariatric surgery, fat loss in the liver and pancreas occurs independently, suggesting a tissue-specific mobilization of the ectopic fat deposits [13, 29].

Lifestyle measures such as very-low-fat eating and intensive training could be expected to work in a complementary way by promoting an increased number of insulin receptors that are more functionally competent [87].
Promising results for drug-based therapies

Although until now there is no approved pharmacological therapy for NAFPD, it seems that treatment with oral hypoglycemic agents, such as metformin, DPP-4 inhibitors and thiazolidinediones in T2DM subjects showed encouraging results. Metformin is a first-line antidiabetic drug with favorable effect on lipid metabolism [88].

Studies on rats proved that metformin, by decreasing oxidative stress in pancreatic islets, might have a direct beneficial effect on insulin secretion [89]. It improves insulin resistance and suppresses the compensatory $\beta$-cell hyperplasia induced by high-fat diet [90], therefore it might reduce visceral fatty tissue.

Incretin-based therapies, especially DPP-4 inhibitors (Sitagliptin), in monotherapy and combined with metformin, reduced pancreatic adiposity [91].

Troglitazone, the first thiazolidinedione, withdrawn in 2000 because of the frequent adverse liver reactions, including acute liver failure, decreases hepatic glucose output and increases insulin-dependent glucose disposal in the skeletal muscle. The metabolic changes induced by troglitazone result from the increased responsiveness of insulin-dependent tissues [92] and are observed in numerous animal models of insulin resistance. Although treatment did not affect pancreatic weight or islet number, it increased granulation of the pancreatic beta cells in rodent models of insulin resistance. Several studies in mice suggest that troglitazone prevented hyperglycemia, hyperlipidemia, and the increase in 11 $\beta$-HSD1 (an enzyme that reduces cortisone to cortisol, reducing the risk of central obesity development) [93]. Troglitazone was also associated with a $52 \%$ decrease in islet triglycerides, exerting direct lipopenic activity in normal islets and in the islets of obese prediabetic rats [94].

By suppressing inflammatory changes in the pancreas, troglitazone treatment completely prevented or reversed histological alterations such as fibrosis, fatty replacement, and inflammatory cell infiltration [95].

Studies with new generation thiazolidinedione on NAFPD are missing.

It has been shown that the activation of a local renin-angiotensin system contributes to insulin resistance and non-alcoholic fatty liver disease onset [96], therefore Angiotensin type-1 receptor (AT1R) blockers might mitigate insulin resistance and fatty liver by enhancing beta-oxidation, reducing lipogenesis and controlling inflammation [97].

Based on this fact, some authors used Telmisartan, Sitagliptin and Metformin in monotherapy or in combinations (telmisartan + metformin, 
telmisartan + sitagliptin, sitagliptin + metformin) to evaluate their effects on insulin resistance and on pancreatic and hepatic adipose tissue distribution in mice fed on a high-fat diet. All drug treatments had the effect of reducing body weight, and also pancreatic and hepatic steatosis. The best results were observed with telmisartan and sitagliptin, associated or as monotherapies [98]. In a follow-up study, complete reversal of pancreatic steatosis was achieved using telmisartan and sitagliptin combination [99].

Another study on obese rats highlighted that Sandostatin (somatostatin analogue) might improve pancreatic fatty infiltration, lipid disorder, insulin resistance, and alleviate pancreatic injury by downregulating the expression of adipose differentiationrelated protein in the pancreas [100].

Studies have also researched IL-10 and some homeopathic remedies such as berberine and cinnamic acid [101-104], but further evidence to support their benefits in FP is needed.

\section{CONCLUSIONS}

NAFPD is a new but very common pathological entity which is not readily recognized in clinical practice, although easily diagnosable with good imaging of the pancreas. It could be considered the pancreatic manifestation of MetS and it should be searched for in each patient who meets criteria for MetS. It is not just another target for ectopic fat deposition, but it has significant metabolic consequences. Diagnostic work-up includes pancreatic imaging, starting with routine ultrasound and confirming with advanced imagery. There is no standard treatment for NAFPD, but weight control by lifestyle measures or bariatric endoscopy/surgery and antidiabetic drugs showed promising results.

Conflict of Interest disclosure: The authors declare that there are not conflicts of interest.

\begin{abstract}
Abbreviations: NAFPD: non-alcoholic fatty pancreas disease; NAFLD: non-alcoholic fatty liver disease; FP:fatty pancreas; MetS: metabolic syndrome; BMI: Body Mass Index; AP: acute pancreatitis; PF: pancreatic fistula; TNF- $\alpha$ : Tumor necrosis factor- $\alpha$; IL-6: Interleukin 6; T2DM: type 2 diabetes mellitus; US: transabdominal ultrasound; EUS: endoscopic ultrasound; RTE: real-time elastography; CT: computed-tomography; MRI: magnetic resonance imaging; FNA: guided fine needle aspiration; ChP: chronic pancreatitis; EPI: exocrine pancreatic insufficiency; FE-1: fecal elastase-1; PC: pancreatic cancer; DPP-4: dipeptidyl peptidase 4 ; $11 \beta$-HSD1: $11 \beta$-hydroxysteroid dehydrogenase type 1; AT1R: angiotensin type-1 receptor; IL-10: Interleukin 10.
\end{abstract}

Obezitatea reprezintă o povară din ce în ce mai mare la nivel mondial, crescând riscul pentru mai multe patologii care intră în componența sindromului metabolic - diabetul zaharat tip 2, dislipidemia, ficatul gras non-alcoolic şi bolile cardiovasculare. Odată cu cresterea frecvenței obezității, o nouă entitate patologică s-a conturat în cadrul sindromului metabolic, cea a pancreasului gras non-alcoolic (NAFPD). Similar cu ficatul gras non-alcoolic (NAFLD), NAFPD cuprinde un spectru larg de afectare pancreatică - de la steatoză până la inflamația pancreasului şi posibil fibroză pancreatică. Spre deosebire de NAFLD, testele diagnostice pentru NAFPD sunt mai puțin standardizate, constând în metode imagistice. De asemenea, evoluția naturală a NAFPD şi asocierea acesteia cu cancerul pancreatic este mult mai puțin cunoscută. $N u$ in ultimul rând, consecințele clinice ale NAFPD rămân în mare parte prezumții, iar cunoştințele impactului său metabolic sunt limitate. Acest review sumarizează cunoştințele actuale despre epidemiologia, patogeneza, testele diagnostic şi opțiunile de tratament pentru NAFPD, cu accent pe practica clinică.

Correspondence to: Balaban Daniel Vasile, MD, PhD, 37 Dionisie Lupu, UMF Carol Davila, 030167, Bucharest, Romania, Phone: + 40742519793

E-mail: vasile.balaban@umfcd.ro

\section{REFERENCES}

1. ALEMPIJEVIC T., DRAGASEVIC S., ZEC S., POPOVIC D., MILOSAVLJEVIC T. Non-alcoholic fatty pancreas disease. Postgrad Med J 2017; 93(1098):226-230.

2. SMITS M.M., VAN GEENEN E.J.M. The clinical significance of pancreatic steatosis. Nat Rev Gastroenterol Hepatol 2011; 8(3): 169-177. 
3. ROMANA B.S., CHELA H., DAILEY F.E., NASSIR F., TAHAN V. Non-alcoholic fatty pancreas disease (NAFPD). A silent spectator or the fifth component of metabolic syndrome? A literature review. Endocrine Metab Immune Disord - Drug Targets 2018; 18(6): 547-554.

4. OU H.-Y., WANG C.-Y., YANG Y.-C., CHEN M.-F., CHANG C.-J. The association between nonalcoholic fatty pancreas disease and diabetes. PloSOne 2013; 8(5): e62561.

5. OGILVIE R.F. The islands of langerhans in 19 cases of obesity. J. Pathol. Bacteriol. 1993; 37(3): 473-481.

6. WANG C., OU H., CHEN M., CHANG T., CHANG C. Enigmatic ectopic fat: prevalence of nonalcoholic fatty pancreas disease and its associated factors in a Chinese population. J AmHeart Assoc 2014: 3(1): e000297.

7. LESMANA C.R.A., PAKASI L.S., INGGRIANI S., AIDAWATI M.L., LESMANA L.A. Prevalence of non-alcoholic fatty pancreas disease (nafpd) and its risk factors among adult medical check-up patients in a private hospital: a large cross sectional study. BMCGastroenterol. 2015; 15: 174.

8. ZHOU J., LI M.L., ZHANG D.D., LIN H.Y., DAI X.H., SUN X.L. et al. The correlation between pancreatic steatosis and metabolic syndrome in a Chinese population. Pancreatology 2016; 16(4): 578-83.

9. UYGUN A, KADAYIFCI A, DEMIRCI H, SAGLAM M, SAKIN YS, OZTURK K et al. The effect of fatty pancreas on serum glucose parameters in patients with nonalcoholic steatohepatitis. Eur. J. Intern. Med 2015; 26(1): 37-41.

10. AL-HADDAD M, KHASHAB M, ZYROMSKI N, PUNGPAPONG S, WALLACE MB, SCOLAPIO J et al. Risk factors for hyperechogenic pancreas on endoscopic ultrasound: a case-control study. Pancreas 2009; 36(6): 672-5.

11. SCHWENZER NF, MACHANN J, MARTIROSIAN P, STEFAN N, SCHRAML C, FRITSCHE A et al. Quantification of pancreatic lipomatosis and liver steatosis by MRI: Comparison of in/opposed-phase and spectral-spatial excitation techniques. Invest. Radiol. 2008; 43(5): 330-337.

12. HENI M, MACHANN J, STAIGER H, SCHWENZER NF, PETER A, SCHICK F et al. Pancreatic fat is negatively associated with insulin secretion in individuals with impaired fasting glucose and/or impaired glucose tolerance: a nuclear magnetic resonance study. Diabetes. Metab. Res. Rev. 2010; 26(3) 200-205.

13. GABORIT B, ABDESSELAM I, KOBER F, JACQUIER A, RONSIN O, EMUNGANIA O, et al. Ectopic fat storage in the pancreas using 1H-MRS: importance of diabetic status and modulation with bariatric surgery-induced weight loss.Int. J. Obes. 2015; 39(3): 480-487.

14. VAN GEENEN E.-J.M., SMITS M. M., SCHREUDER T. C.M.A., VAN DER PEET D.L., BLOEMENA E., MULDER C.J.J. Nonalcoholic fatty liver disease is related to nonalcoholic fatty pancreas disease. Pancreas 2010; 39(8): 1185-1190.

15. PACIFICO L, DI MARTINO M, ANANIA C, ANDREOLI GM, BEZZI M, CATALANO C et al. Pancreatic fat and $\beta$-cell function in overweight/obese children with nonalcoholic fatty liver disease. World J. Gastroenterol. 2015; 21(15): 4688-4695.

16. TARGHER G, ROSSI AP, ZAMBONI GA, FANTIN F, ANTONIOLI A, CORZATO F et al. Pancreatic fat accumulation and its relationship with liver fat content and other fat depots in obese individuals. J. Endocrinol. Invest. 2012; 35(8): 748-753.

17. LINGVAYI, ESSER V, LEGENDRE JL, PRICE AL, WERTZ KM, ADAMS-HUET B et al. Noninvasive quantification of pancreatic fat in humans. J. Clin. Endocrinol. Metab. 2009; 94(10): 4070-4076.

18. ROSSI AP, FANTIN F, ZAMBONI GA, MAZZALI G, RINALDI CA, DEL GIGLIO M. et al. Predictors of ectopic fat accumulation in liver and pancreas in obese men and women. Obesity (Silver Spring). 2011; 19(9): 1747-1754.

19. WU W.-C., WANG C.-Y. Association between non-alcoholic fatty pancreatic disease (NAFPD) and the metabolic syndrome: case-control retrospective study. Cardiovasc. Diabetol. 2013; 12: 77.

20. LI S., SU L., LV G., ZHAO W., CHEN J. Transabdominal ultrasonography of the pancreas is superior to that of the liver for detection of ectopic fat deposits resulting from metabolic syndrome. Medicine (Baltimore) 2017; 96 (37): e8060.

21. WENG S., ZHOU J., CHEN X., SUN Y., MAO Z., CHAI K. Prevalence and factors associated with nonalcoholic fatty pancreas disease and its severity in China. Medicine (Baltimore). 2018; 97 (26): e11293.

22. LEE SE, JANG JY, LIM CS, KANG MJ, KIM SH, KIM MA et al. Measurement of pancreatic fat by magnetic resonance imaging: predicting the occurrence of pancreatic fistula after pancreatoduodenectomy. Ann. Surg. 2010; 51 (251): 932-936.

23. NAVINA S, ACHARYA C, DELANY JP, ORLICHENKO LS, BATY CJ, SHIVA SS et al. Lipotoxicity causes multisystem organ failure and exacerbates acute pancreatitis in obesity. Sci. Transl. Med 2011; 3 (107): 107ra110.

24. ACHARYA C, CLINE RA, JALIGAMA D, NOEL P, DELANY JP, BAE K et al. Fibrosis reduces severity of acute-on-chronic pancreatitis in humans. Gastroenterology 2013; 145 (2): 466-475.

25. SEPE PS, OHRI A, SANAKA S, BERZIN TM, SEKHON S, BENNETT G et al. A prospective evaluation of fatty pancreas by using EUS. Gastrointest. Endosc. 2011; 73 (5): 987-993.

26. ACHARYA C., NAVINA S., SINGH V.P. Role of pancreatic fat in the outcomes of pancreatitis. Pancreatology 2014; 14 (5): 403-408.

27. ROSSO E, CASNEDI S, PESSAUX P, OUSSOULTZOGLOU E, PANARO F, MAHFUD M et al. The role of \&quot;fatty pancreas\&quot; and of BMI in the occurrence of pancreatic fistula after pancreaticoduodenectomy. J. Gastrointest. Surg., 2009; 13 (10): 1845-1851.

28. TOMITA Y, AZUMA K, NONAKA Y, KAMADA Y, TOMOEDA M, KISHIDA M et al. Pancreatic fatty degeneration and fibrosis as predisposing factors for the development of pancreatic ductal adenocarcinoma. Pancreas 2014; 43 (7): $1032-1041$.

39. CATANZARO R., CUFFARI B., ITALIA A., MAROTTA F. Exploring the metabolic syndrome: Nonalcoholic fatty pancreas disease. World J. Gastroenterol. 2016; 22(34): 7660-7675.

30. VIRTUE S., VIDAL-PUIG A. It's not how fat you are, it's what you do with it that counts. PLoS Biol. 2008; 6(9): e237.

31. SKURK T., ALBERTI-HUBER C., HERDER C., HAUNER H. Relationship between adipocyte size and adipokine expression and secretion. J. Clin. Endocrinol. Metab. 2007; 92(3):1023-1033.

32. BLÜHER M. Adipose tissue dysfunction in obesity. Exp. Clin. Endocrinol. Diabetes 2009; 117 (06): 241-250.

33. SCHA J.E. Lipotoxicity: when tissues overeat. Curr. Opin. Lipidol.2003; 14 (3): 281-287.

34. YE J. Mechanisms of insulin resistance in obesity. Front. Med. 2013; 7 (1): 14-24. 
35. PINNICK K.E., COLLINS S.C., LONDOS C., GAUGUIER D., CLARK A., FIELDING B.A. Pancreatic ectopic fat is characterized by adipocyte infiltration and altered lipid composition. Obesity 2008; 16 (3): 522-530.

36. MARKS W.M., FILLY R.A., CALLEN P.W. Ultrasonic evaluation of normal pancreatic echogenicity and its relationship to fat deposition. Radiology 1980; 137 (2): 475-9.

37. NGHIEM D.D., OLSON P.R., ORMOND D. The fatty pancreas allograf T anatomopathologic findings and clinical experience. Transplant. Proc. 2004; 36 (4): 1045-1047.

38. WALTERS M.N. Adipose atrophy of the exocrine pancreas. J. Pathol. Bacteriol. 1996; 92 (2): 547-557.

39. WELLEN K.E., HOTAMISLIGIL G.S. Inflammation, stress, and diabetes. J. Clin. Invest 2005; 115 (5): 1111-1119.

40. VAN RAALTE D.H., VAN DER ZIJL N.J., DIAMANT M. Pancreatic steatosis in humans: cause or marker of lipotoxicity? Curr. Opin. Clin. Nutr. Metab. Care 2010; 13 (4): 478-485.

41. TSATSOULIS A., MANTZARIS M.D., BELLOU S., ANDRIKOULA M. Insulin resistance: An adaptive mechanism becomes maladaptive in the current environment - An evolutionary perspective. Metabolism 2013; 62 (5): 622-633.

42. UNGER R.H., SCHERER P.E. Gluttony, sloth and the metabolic syndrome: a roadmap to lipotoxicity. Trends Endocrinol. Metab. 2010; 21 (6): 345-352.

43. LEE JS, KIM SH, JUN DW, HAN JH, JANG EC, PARK JY et al. Clinical implications of fatty pancreas: correlations between fatty pancreas and metabolic syndrome. World J. Gastroenterol. 2009; 15 (15): 1869-1875.

44. Then and now: ATP III vs. IV - American College of Cardiology [Online]. Available: https://www.acc.org/latest-incardiology/articles/2014/07/18/16/03/then-and-now-atp-iii-vs-iv. [Accessed: 29-Nov-2018].

45. MATSUMOTO S, MORI H, MIYAKE H, TAKAKI H, MAEDA T, YAMADA Y et al. Uneven fatty replacement of the pancreas: evaluation with CT. Radiology 1995; 194(2): 453-458.

46. KÜHN JP, BERTHOLD F, MAYERLE J, VÖLZKE H, REEDER SB, RATHMANN W et al. Pancreatic steatosis demonstrated at MR imaging in the general population: clinical relevance. Radiology 2015; 276 (1):129-136.

47. CHANTAROJANASIRI T., HIROOKA Y., RATANACHU-EK T., KAWASHIMA H., OHNO E., GOTO H. Evolution of pancreas in aging: degenerative variation or early changes of disease? J. Med. Ultrason. 2015; 42 (2): 177-183.

48. JEONG H.T., LEE M.S., KIM M.-J. Quantitative analysis of pancreatic echogenicity on transabdominal sonography: correlations with metabolic syndrome. J. Clin. Ultrasound 2015; 43 (2): 98-108.

49. POLKOWSKI M, JENSSEN C, KAYE P, CARRARA S, DEPREZ P, GINES A et al. Technical aspects of endoscopic ultrasound (EUS)-guided sampling in gastroenterology: European Society of Gastrointestinal Endoscopy (ESGE) Technical guideline - March 2017. Endoscopy 2017; 49(10): 989-1006.

50. CHOI CW, KIM GH, KANG DH, KIM HW, KIM DU, HEO J et al. Associated factors for a hyperechogenic pancreas on endoscopic ultrasound. World J. Gastroenterol. 2010; 16 (34): 4329-34.

51. USTUNDAG Y., CEYLAN G., HEKIMOGLU K. Pancreatic hyperechogenicity on endoscopic ultrasound examination. World J. Gastroenterol. 2011; 17 (15): 2061-2062.

52. COSGROVE D, PISCAGLIA F, BAMBER J, BOJUNGA J, CORREAS JM, GILJA OH et al. EFSUMB guidelines and recommendations on the clinical use of ultrasound elastography. Part 2: clinical applications. Ultraschall der Medizin - Eur. J. Ultrasound 2013; 34 (03): 238-253.

53. KUWAHARA T, HIROOKA Y, KAWASHIMA H, OHNO E, YOKOYAMA Y, FUJII T et al. Usefulness of endoscopic ultrasonography-elastography as a predictive tool for the occurrence of pancreatic fistula after pancreatoduodenectomy. J. Hepatobiliary. Pancreat. Sci. 2017; 24 (12): 649-656.

54. BARRETO S.G., DIRKZWAGER I., WINDSOR J.A., PANDANABOYANA S. Predicting post-operative pancreatic fistulae using preoperative pancreatic imaging: a systematic review. ANZ J. Surg. 2018 [Epub ahead of print].

55. MATHUR A, HERNANDEZ J, SHAHEEN F, SHROFF M, DAHAL S, MORTON C et al. Preoperative computed tomography measurements of pancreatic steatosis and visceral fat: prognostic markers for dissemination and lethality of pancreatic adenocarcinoma. HPB (Oxford). 2011; 13(6): 404-10.

56. TRANCHART H, GAUJOUX S, REBOURS V, VULLIERME MP, DOKMAK S, LEVY P et al. Preoperative CT scan helps to predict the occurrence of severe pancreatic fistula after pancreaticoduodenectomy. Ann. Surg. 2012; 256 (1): 139-145.

57. ROBERTS K.J., STOREY R., HODSON J., SMITH A.M., MORRIS-STIFF G. Pre-operative prediction of pancreatic fistula: is it possible?, Pancreatology 2013; 13(4) 423-428.

58. SAISHO Y, BUTLER AE, MEIER JJ, MONCHAMP T, ALLEN-AUERBACH M, RIZZA RA et al. Pancreas volumes in humans from birth to age one hundred taking into account sex, obesity, and presence of type-2 diabetes. Clin. Anat. 2007; 20(8): 933-942.

59. KIM SY, KIM H, CHO JY, LIM S, CHA K, LEE KH et al. Quantitative assessment of pancreatic fat by using unenhanced CT: pathologic correlation and clinical implications. Radiology 2014; 271 (1): 104-112.

60. HU H.H., KIM H.-W., NAYAK K.S., GORAN M.I. Comparison of fat-water MRI and single-voxel MRS in the Assessment of hepatic and pancreatic fat fractions in humans. Obesity 2010; 18(4): 841-847.

61. LIVINGSTONE RS, BEGOVATZ P, KAHL S, NOWOTNY B, STRASSBURGER K, GIANI G et al. Initial clinical application of modified Dixon with flexible echo times: hepatic and pancreatic fat assessments in comparison with $1 \mathrm{H}$ MRS. Magn. Reson. Mater. Physics. Biol. Med. 2014; 27(5): 397-405.

62. MA J., SONG Z., YAN F. Detection of hepatic and pancreatic fat infiltration in type II diabetes mellitus patients with IDEALQuant using 3.0T MR: comparison with single-voxel proton spectroscopy. Chin. Med. J. (Engl). 2014; 127 (20): 3548-52.

63. OLSEN T.S. Lipomatosis of the pancreas in autopsy material and its relation to age and overweight. Acta Pathol. Microbiol. Scand. A. 1978; 86A(5): 367-73.

64. WONG VW, WONG GL, YEUNG DK, ABRIGO JM, KONG AP, CHAN RS et al. Fatty pancreas, insulin resistance, and $\beta$ cell function: a population study using fat-water magnetic resonance imaging. Am. J. Gastroenterol. 2014; 109 (4): $589-597$. 
65. YAMAZAKI H, TSUBOYA T, KATANUMA A, KODAMA Y, TAUCHI S, DOHKE M et al. Lack of independent association between fatty pancreas and incidence of type 2 diabetes: 5-year Japanese cohort study. Diabetes Care2016; 39 (10): 1677-1683.

66. KIM MK, CHUN HJ, PARK JH, YEO DM, BAEK KH, SONG KH et al. The association between ectopic fat in the pancreas and subclinical atherosclerosis in type 2 diabetes. Diabetes Res. Clin. Pract. 2014; 106 (3): 590-596.

67. MATHUR A, PITT HA, MARINE M, SAXENA R, SCHMIDT CM, HOWARD TJ et al. Fatty pancreas. Ann. Surg. $2007 ; 246$ (6): 1058-1064.

68. CAVALLINI G., FRULLONI L., VAONA B., DI FRANCESCO V., BOVO P. Is hyperamylasemia related to dyslipidemia? Gastroenterology 1997; 112 (3): 1058-059.

69. GULLO L., LUCREZIO L., MIGLIORI M., BASSI M., NESTICÒ V., COSTA P.L. Benign pancreatic hyperenzymemia or Gullo's syndrome. Adv. Med. Sci. 2008; 53(1): 1-5.

70. KHAN N.A., AMIN M.S., ISLAM M.Z. Pancreatic lipomatosis with massive steatorrhea. Mymensingh Med. J. $2011 ; 20$ (4): 712-714.

71. LOZANO M, NAVARRO S, PÉREZ-AYUSO R, LLACH J, AYUSO C, GUEVARA MC et al. Lipomatosis of the pancreas: an unusual cause of massive steatorrhea. Pancreas 1988; 3(5): 580-582.

72. AUBERT A, GORNET JM, HAMMEL P, LÉVY P, O'TOOLE D, RUSZNIEWSKI P et al. Diffuse primary fat replacement of the pancreas: an unusual cause of steatorrhea. Gastroenterol. Clin. Biol. 2007; 31 (3): 303-306.

73. AMBESH P., LAL H. Pancreatic lipomatosis: complete replacement of pancreas by fat. J. Clin. Diagn. Res. 2015 ; 9 (10): OL01.

74. PRASANNA KUMAR H.R., GOWDAPPA H.B., HOSMANI T., URS T. Exocrine dysfunction correlates with endocrinal impairment of pancreas in type 2 diabetes mellitus. Indian J. Endocrinol. Metab. 2018; 22 (1): 121-125.

75. HARDT PD, HAUENSCHILD A, NALOP J, MARZEION AM, JAEGER C, TEICHMANN J, et al. High prevalence of exocrine pancreatic insufficiency in diabetes mellitus. A multicenter study screening fecal elastase 1 concentrations in 1,021 diabetic patients. Pancreatology 2003; 3 (5): 395-402.

76. ČABARKAPA V, DJERIĆ M, MITROVIĆ M, KOJIĆ-DAMJANOV S, ISAKOV I, VUKOVIĆ B et al. Fecal pancreatic elastase-1 and erythrocyte magnesium levels in diabetes type 1 and type 2. Magnes. Res. 2018; 31 (1): 1-10.

77. TERZIN V, VÁRKONYI T, SZABOLCS A, LENGYEL C, TAKÄCS T, ZSÓRI G et al. Prevalence of exocrine pancreatic insufficiency in type 2 diabetes mellitus with poor glycemic control. Pancreatology 2014; 14 (5): 356-60.

78. ESPOSITO K., CHIODINI P., COLAO A., LENZI A., GIUGLIANO D. Metabolic syndrome and risk of cancer: a systematic review and meta-analysis. Diabetes Care 2012; 35 (11): 2402-2411.

79. MENDONÇA FM, DE SOUSA FR, BARBOSA AL, MARTINS SC, ARAÚJO RL, SOARES R et al. Metabolic syndrome and risk of cancer: Which link? Metabolism, 2015; 64 (2): 182-189.

80. XU M., JUNG X., HINES O.J., EIBL G., CHEN Y. Obesity and pancreatic cancer: overview of epidemiology and potential prevention by weight loss. Pancreas 2018; 47 (2): 158-162.

81. MATHUR A, ZYROMSKI NJ, PITT HA, AL-AZZAWI H, WALKER JJ, SAXENA R et al. Pancreatic steatosis promotes dissemination and lethality of pancreatic cancer. J. Am. Coll. Surg., 2009; 208 (5): 989-94; discussion 994-996.

82. MALVEZZI M, CARIOLI G, BERTUCCIO P, BOFFETTA P, LEVI F, LA VECCHIA C et al. European cancer mortality predictions for the year 2018 with focus on colorectal cancer. Ann. Oncol. Off. J. Eur. Soc. Med. Oncol. 2018; 29 (4): $1016-1022$.

83. HONKA H, KOFFERT J, HANNUKAINEN JC, TUULARI JJ, KARLSSON HK, IMMONEN H et al. The effects of bariatric surgery on pancreatic lipid metabolism and blood flow. J. Clin. Endocrinol. Metab. 2015; 100 (5): 2015-023.

84. HANSEN E.N., TORQUATI A., ABUMRAD N.N. Results of bariatric surgery. Annu. Rev. Nutr. 2006; 26 (1): $481-511$.

85. CUMMINGS BP, STRADER AD, STANHOPE KL, GRAHAM JL, LEE J, RAYBOULD HE. et al. Ileal interposition surgery improves glucose and lipid metabolism and delays diabetes onset in the UCD-T2DM rat. Gastroenterology 2010; 138 (7): 2437 2446.e1.

86. MALIN S.K., KASHYAP S.R. Effects of various gastrointestinal procedures on $\beta$-cell function in obesity and type 2 diabetes. Surg. Obes. Relat. Dis. 2016; 12 (6): 1213-1219.

87. MCCARTY M.F. Complementary measures for promoting insulin sensitivity in skeletal muscle. Med. Hypotheses $1998 ; 51$ (6): 451-464.

88. WRÓBEL M.P., MAREK B., KAJDANIUK D., ROKICKA D., SZYMBORSKA-KAJANEK A., STROJEK K. Metformin - $a$ new old drug. Endokrynol. Pol. 2017; 68 (4): 482-496.

89. PIRO S., RABUAZZO A.M., RENIS M., PURRELLO F. Effects of metformin on oxidative stress, adenine nucleotides balance, and glucose-induced insulin release impaired by chronic free fatty acids exposure in rat pancreatic islets. J. Endocrinol. Invest. 2012; 35(5): 504-510.

90. TAJIMA K, SHIRAKAWA J, OKUYAMA T, KYOHARA M, YAMAZAKI S, TOGASHI Y et al. Effects of metformin on compensatory pancreatic $\beta$-cell hyperplasia in mice fed a high-fat diet. Am. J. Physiol. Metab. 2017; 313 (3): E367-E380.

91. REIMER R.A., GROVER G.J., KOETZNER L., GAHLER R.J., LYON M.R., WOOD S. Combining sitagliptin/metformin with a functional fiber delays diabetes progression in Zucker rats. J. Endocrinol. 2014; 220 (3): 361-373.

92. LEBOVITZ H.E., BANERJI M.A. Insulin resistance and its treatment by thiazolidinediones. Recent Prog. Horm. Res.2001; 56: 265-294.

93. DUPLOMB L, LEE Y, WANG MY, PARK BH, TAKAISHI K, AGARWAL AK et al. Increased expression and activity of 11beta-HSD-1 in diabetic islets and prevention with troglitazone. Biochem. Biophys. Res. Commun. 2004; 313 (3): 594-599.

94. SHIMABUKURO M., ZHOU Y.T., LEE Y., UNGER R.H. Troglitazone lowers islet fat and restores beta cell function of Zucker diabetic fatty rats. J. Biol. Chem. 1998; 273(6): 3547-3550.

95. JIA D.M., FUKUMITSU K.I., TABARU A., AKIYAMA T., OTSUKI M. Troglitazone stimulates pancreatic growth in congenitally CCK-A receptor-deficient OLETF rats. Am. J. Physiol. Regul. Integr. Comp. Physiol. 2001; 280 (5): R1332-40. 
96. ZHANG W., MIAO J., LI P., WANG Y., ZHANG Y. Up-regulation of components of the renin-angiotensin system in liver fibrosis in the rat induced by CCL4. Res. Vet. Sci. 2013; 95 (1): 54-58.

97. SOUZA-MELLO V. Hepatic structural enhancement and insulin resistance amelioration due to AT1 receptor blockade. World J. Hepatol. 2017; 9 (2): 74-79.

98. SOUZA-MELLO V., GREGÓRIO B.M., CARDOSO-DE-LEMOS F.S., DE CARVALHO L., AGUILA M.B., MANDARIMDE-LACERDA C.A. Comparative effects of telmisartan, sitagliptin and metformin alone or in combination on obesity, insulin resistance, and liver and pancreas remodelling in C57BL/6 mice fed on a very high-fat diet. Clin. Sci. (Lond) $2010 ; 119$ (6): 239-250.

99. SOUZA-MELlO V., GREGÓRIO B.M., RELVAS-LUCAS B., DA SILVA FARIA T., AGUILA M.B., MANDARIM-DELACERDA C.A. Pancreatic ultrastructural enhancement due to telmisartan plus sitagliptin treatment in diet-induced obese C57BL/6 mice. Pancreas 2011; 40 (5): 715-722.

100. YU T, LIU R, LI M, LI X, QIANG O, HUANG W et al. Effects of octreotide on fatty infiltration of the pancreas in high-fat diet induced obesity rats. Wei Sheng Yan Jiu 2014; 43 (2): 186-92.

101.GOTOH K, INOUE M, SHIRAISHI K, MASAKI T, CHIBA S, MITSUTOMI K et al. Spleen-derived interleukin-10 downregulates the severity of high-fat diet-induced non-alcoholic fatty pancreas disease. PLoS One 2012; 7 (12): e53154.

102. TURNER N, LI JY, GOSBY A, TO SW, CHENG Z, MIYOSHI H et al. Berberine and its more biologically available derivative, dihydroberberine, inhibit mitochondrial respiratory complex I: a mechanism for the action of berberine to activate AMP-activated protein kinase and improve insulin action. Diabetes 2008; 57 (5): 1414-1418.

103.ZHANG Z, ZHANG H, LI B, MENG X, WANG J, ZHANG Y et al. Berberine activates thermogenesis in white and brown adipose tissue. Nat. Commun. 2014; 5 (1): 5493.

104. ZHANG Z, ZHANG H, LI B, MENG X, WANG J, ZHANG Y et al. Effects of berberine and cinnamic acid on palmitic acidinduced intracellular triglyceride accumulation in NIT-1 pancreatic $\beta$ cells. Chin. J. Integr.Med.2016; 22 (7): 496-502.

Received December 30, 2018 